\title{
Logistics and financial regulation of the defense-industrial complex in the system of troops
}

\author{
Denys Lisovenko ${ }^{1 *}$, Nadiia Burdeina ${ }^{1}$, Oleksandr Fedchenko $^{1}$, Stanislav Nikul $^{2}$, and \\ Viacheslav Holovan ${ }^{2}$ \\ ${ }^{1}$ Odesa Military Academy, Department of Military Support, 10 Fontanska road Street, Odesa, \\ Ukraine, 65009 \\ ${ }^{2}$ Odesa Military Academy, Rocket and Artillery Weapon Department, 10 Fontanska road Street, \\ Odesa, Ukraine, 65009
}

\begin{abstract}
The study is devoted to the problem of financial regulation of the defense industry and the provision of troops, as the escalation of the military conflict in eastern Ukraine has revealed shortcomings in this area. A comparative analysis of NATO and Ukraine's defense spending was conducted and differences in the cost structure were identified. The tendency of Ukraine's defense spending to gradually approach the structure of NATO defense spending is pointed out, but the insufficient level of this approach is also taken into account. The analysis allowed to identify problematic issues and inconsistencies in the financial regulation of the defense industry. The state of export of defense equipment and technologies as a possible source of financing of defense enterprises is analyzed. The existence of two opposite trends in the financial regulation of military logistics has been identified: both an increase in funding in absolute terms and a reduction in the share of the total amount for the implementation of the unified logistics system of the State Armed Forces Development Program. The developed mathematical model of supply of military units is suitable for use in information systems of logistical support of troops.
\end{abstract}

\section{Introduction}

The Russian Federation has concentrated 28 battalion tactical groups with a total number of about 100 thousand servicemen, up to 1100 tanks, up to 2600 armored personnel carriers, up to 1100 artillery systems near the borders of Ukraine [1]. Russia exercised the transfer of forces for further large-scale offensive operations [2]. This allows Russia to launch offensive operations in any direction without additional mobilization. According to the military doctrine of the Russian Federation, the lack of manpower in large-scale aggression in the absence of a coherent front line and considerable depth raids should be compensated by the high mobility of troops [2]. This level of threat requires significant efforts from Ukraine to form a reliable supply of troops and efficient logistics [3-7].

\footnotetext{
${ }^{1}$ Corresponding author: Lisovenko@email.ua
} 
The study found that the available capacity of enterprises of the military-industrial complex (hereinafter, MIC) is not enough for the simultaneous restoration of damaged military equipment (including during military actions), modernization, creation and serial production of new models for the Armed Forces of Ukraine (hereinafter, Armed Forces) to replace technically, technologically and morally obsolete military equipment that Ukraine got after the collapse of the USSR. The problem of restoration and renewal of the military equipment fleet in the system of troops is complicated by the constant lack of financial resources in the conditions of economic crisis in the country [8-11]. Therefore, the role of budget planning, financial regulation and the use of modern technologies to create effective military logistics is significantly enhanced.

\section{Empirical results and discussion}

Comparison of budget expenditures for defense of NATO and Ukraine indicates their significant difference $[12,13,14,15,16,17]$. According to the study, the budget of NATO countries shows three main blocks: the cost of personnel (Personnel Expenditure) 30 $50 \%$; operating costs (including training of troops $\sim 25 \%$; costs of research and development (hereinafter, R \& D) in the field of defense (Defense R\&T Expenditure) $\leq 10 \%$ and costs of purchasing defense equipment (Defence Equipment Procurement Expenditure) $\sim 20-30 \%$ [13] For the period up to 2014, the item of expenditures for the maintenance of personnel of the Armed Forces was the main part of the defense budget of Ukraine (for example, in 2010 this part was $87.9 \%$ of the total defense budget), which resulted in the impossibility of long-term development of the armed forces [18].

Table 1. Poland's defense spending as an example of NATO defense spending.

\begin{tabular}{|l|c|c|c|c|c|c|}
\hline \multirow{2}{*}{ Expenditure } & \multicolumn{7}{c|}{ Years } \\
\cline { 2 - 7 } & $\mathbf{2 0 1 2}$ & $\mathbf{2 0 1 3}$ & $\mathbf{2 0 1 4}$ & $\mathbf{2 0 1 5}$ & $\mathbf{2 0 1 6}$ & $\mathbf{2 0 1 7}$ \\
\hline Total Defence, MIn $\boldsymbol{€}$ & 6754 & 6720 & 7565 & 9546 & 8500 & 8683 \\
\hline \% of GDP & 1.7 & 1.7 & 1.8 & 2.2 & 2.0 & 1.9 \\
\hline Personnel, MIn $\boldsymbol{€}$ & 3406.8 & 3497.7 & 3544.1 & 3604.3 & 3533.7 & 3823.6 \\
\hline Defence Investment, MIn $\boldsymbol{€}$ & 1542.9 & 1452.4 & 2027.7 & 3152.5 & 1850.4 & 2321.0 \\
\hline $\begin{array}{l}\text { Operation \& Maintenance, } \\
\text { Mln } \boldsymbol{€}\end{array}$ & 1330.7 & 1272.5 & 1458.2 & 1823.4 & 1898.8 & 1918.1 \\
\hline
\end{tabular}

A typical example for comparison is a NATO country such as Poland. This country is chosen from all NATO countries because it is the most correct basis for comparison. Poland borders Ukraine, was a member of the Warsaw Pact and the state of military equipment and logistics, the procedure for budgeting defense spending of this country is comparable to the defense of Ukraine (Table 1) and (Table 2) [12-15, 19, 20].

Table 2. Volumes of production of armaments and military equipment by defense enterprises by volume (UAH million) and as a share of total production (\%).

\begin{tabular}{|c|c|c|c|c|c|c|c|c|}
\hline \multirow{3}{*}{ 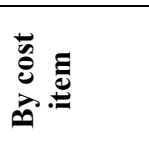 } & \multicolumn{8}{|c|}{ Production volumes } \\
\hline & \multicolumn{2}{|c|}{2016} & \multicolumn{2}{|c|}{2017} & \multicolumn{2}{|c|}{2018} & \multicolumn{2}{|c|}{2019} \\
\hline & $\begin{array}{c}\mathrm{UAH} \\
\text { million }\end{array}$ & $\%$ & $\begin{array}{c}\mathrm{UAH} \\
\text { million }\end{array}$ & $\%$ & $\begin{array}{c}\mathrm{UAH} \\
\text { million }\end{array}$ & $\%$ & $\begin{array}{c}\mathrm{UAH} \\
\text { million }\end{array}$ & $\%$ \\
\hline R\&D & 352.2 & 2.64 & 516.6 & 3.16 & 1453.0 & 5.7 & 574.0 & 10.0 \\
\hline Purchase & 4920 & 36.8 & 5571 & 34.0 & 113581 & 44.6 & 3229 & 56.1 \\
\hline Repairs & 4741 & 35.47 & 5821 & 35.6 & 8625 & 33.8 & 1953 & 33.9 \\
\hline $\begin{array}{c}\text { Serial } \\
\text { production }\end{array}$ & 2895 & 21.66 & 4376 & 26.7 & 3797 & 14.8 & No data & No data \\
\hline
\end{tabular}


A comparative analysis of the data presented in Table 1 and Table 2 indicates a gradual approximation of Ukraine's defense spending, year after year, according to manufacturers' reports, in terms of research expenditures to the level of NATO countries $(10 \%)$. At the same time, the required level of R\&D funding in Ukraine has not been achieved to date. In particular, it should be noted the inadequate amount of funding for the preparation of the production of new models of military equipment by the Ministry of Economic Development of Ukraine [18, 21-24].

Problematic issues in this area, in particular, are: shortcomings in planning and financial regulation in the defense production system, which lead to inconsistencies in the simultaneous fulfillment of R\&D and mass production within one enterprise, resulting in reduced R\&D quality and/or increased cost of military equipment; significant funds advanced by the state for these purposes are not allocated by producers on a separate account, which allows the funds to be redistributed to other, non-targeted, cost items, which significantly reduces the efficiency of financial resources (actually using advanced money as an interest-free public loan of up to $80 \%$ of the cost of the order for a grace period of up to 5 years).

The cost of purchasing defense equipment far exceeds the cost standards for these purposes of NATO countries, as the task of providing Ukrainian troops with modern equipment in exchange for morally and technologically obsolete one is extremely urgent.

The increase or decrease in the share of expenditures under the article "Repair of military equipment" accompanies more or less intensive phases of military actions.

During the period 2017-2019, a tendency for reduction of series production was revealed. This is due to both the acute problem in procurement and the presence in the nomenclature of mass production of a certain number of obsolete samples.

According to the study, in addition to the lack of budget funding, there are limited opportunities for adequate funding, as well as the fact that defense companies and concerns are not able to fully compensate for the lack of cash resources from military equipment and technology (see Table 3) [25-27].

The study also found that a significant deterrent to the effective development of the defense industry is the inconsistency of the regulatory framework for the formation of the price of defense industry products and limiting profits to up to five percent of the company's costs from purchasing components and services of other companies and only thirty percent of other own production costs in the cost of production.

This leads to the fact that the level of profit of defense enterprises is $\sim 5.4-8 \%$. The profits of defense companies are reduced to this level by "Guidelines for common approaches in the application of certain provisions defined by the Cabinet of Ministers №517 from 08.08.2016" approved by the Ministry of Defence of Ukraine in order to reduce budget expenditures [14]. This decision of the Defence Ministry achieved the goal to reduce government spending, but, on the other hand, it also limited the ability of defense companies to use their own funds to finance their own developments without spending time on coordination and further expectations of budget funding, which otherwise would significantly accelerate the introduction of new models needed by the troops $[12,28,29$, 31].

The results of the analysis indicate that inadequate attention to the defense industry, inadequate state funding of defense companies for the period 1991-2013, lack of effective control over the activities of defense companies by government agencies and civil society has led to a significant reduction in the export potential of the defense industry. Therefore, adequate and effective budget funding remains the financial basis not only for development, but for the very existence of state concerns and enterprises. 
Table 3. Indicators and general characteristics of export opportunities of the defense industry of Ukraine.

\begin{tabular}{|l|l|}
\hline \multicolumn{1}{|c|}{ Indicators } & \multicolumn{1}{c|}{ Details } \\
\hline Directions & Gulf countries, Southeast Asia and China. \\
\hline Structure & $\begin{array}{l}\text { Armored vehicles, warships, military equipment, } \\
\text { modernization of previously exported equipment. }\end{array}$ \\
\hline Revenue & $\sim \$ 30$ million per year. \\
\hline $\begin{array}{l}\text { Control by government agencies } \\
\text { and civil society }\end{array}$ & Low, which leads to a loss of defense technology. \\
\hline $\begin{array}{l}\text { Use of export opportunities of the } \\
\text { defense industry }\end{array}$ & $\begin{array}{l}\leq 25 \% \text {. Non-systemic nature of export contracts. Small share } \\
\text { of the number of contracts per year. }\end{array}$ \\
\hline
\end{tabular}

The analysis showed that the country's leadership has taken this issue into account. Expenditures on the development of armaments and military equipment of Ukraine compared to the state before the aggression of the Russian Federation (2020 to 2014) increased 35.5 times (Fig. 1) [14, 15]. Most of these expenditures are directed to enterprises of the national defense industry [14, 30-33]. This strengthens the material and technical support of the troops.

The dynamics of expenditures for the development of armaments and military equipment of Ukraine is shown in Fig. 1.

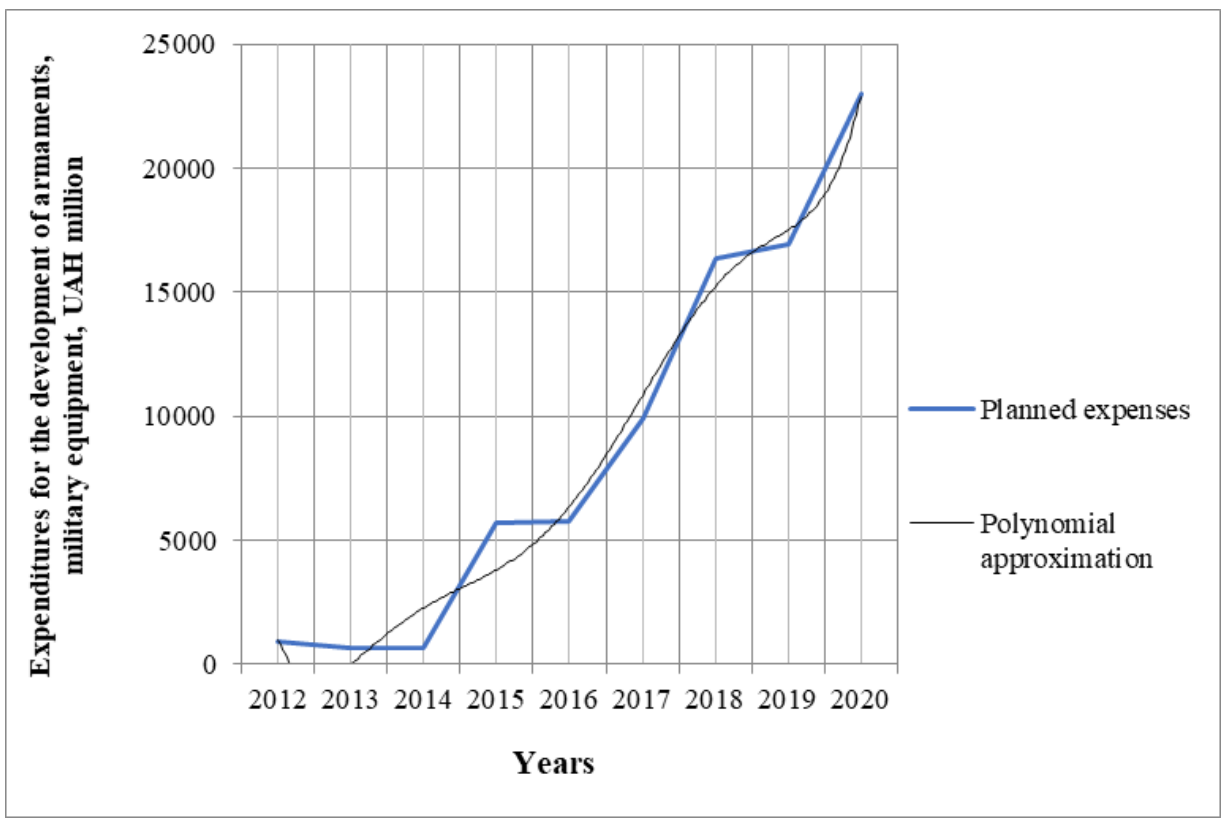

Fig. 1. Expenditures for the development of armaments, military equipment, UAH million.

To conduct the study, expenditures on the development of armaments and military equipment are approximated by the polynomial equation:

$$
y=6,4609 x^{6}-190,54 x^{5}+2191 x^{4}-12445 x^{3}+36715 x^{2}-51370 x+26092
$$




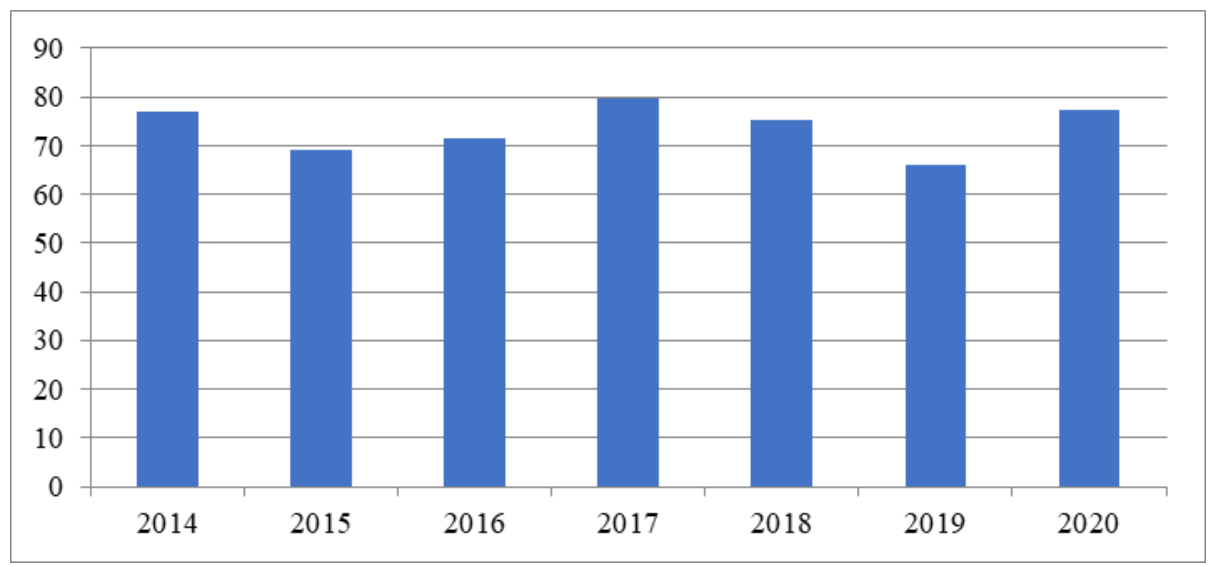

Fig. 2. The ratio of planned funds and cash costs, $\%$.

The study of the dynamics of expenditures on the development of armaments and military equipment of Ukraine indicates that the periods of rapid growth of expenditures (2014-2015, 2016-2018, 2019-2020) are replaced by periods of some stabilization (20182019). The presence of these periods cannot be explained only by the lack of financial capacity of the state to strengthen the appropriate level of defense capabilities. There is also a lack of a proper system for managing financial and material resources in the defense sector.

The study found a systematic gap between the planned amounts in the state budget and cash expenditures for defense needs (Fig. 2) [14]. The data of the diagram (Fig. 2) show that the annual cash expenditures for defense purposes for the period under study did not exceed $80 \%$ of the planned funds. They reached the lowest level in 2019. This is confirmed by the data of Figs. 3, which shows the planned expenditures under the rearmament program and the funds spent on it in fact [14]. The study of the identified trend (equation 1) indicates the need to reduce the adaptive periods for institutional and institutionary structures in order to avoid significant gaps between the planned funds and cash expenditures.

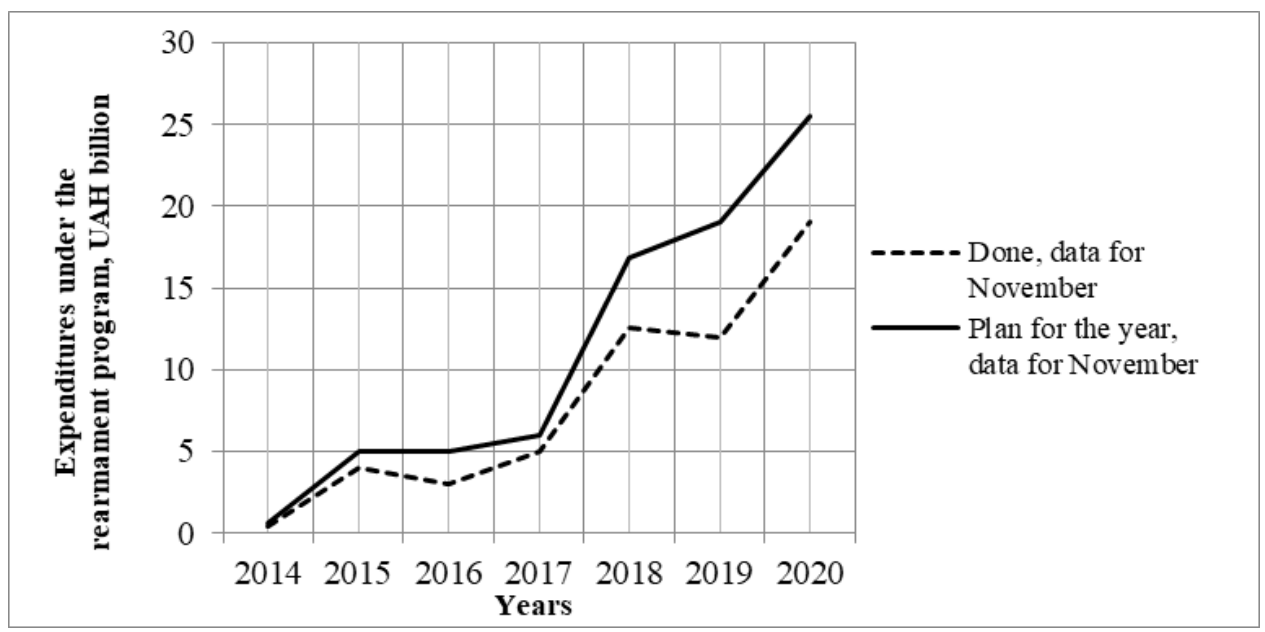

Fig. 3. Expenditures under the rearmament program, UAH billion. 
According to the study, one of the main reasons for the gap between planned expenditures and cash expenditures is the uneven quarterly allocation of money by the Ministry of Finance. The Ministry of Finance allocates the bulk of budget amounts, as a rule, in the last quarter of the financial year, which significantly reduces the ability of the Ministry of Defence of Ukraine (hereinafter, MDU) to effectively use these funds in full. In particular, as it is established by the study, the MDU is forced to use the advance form of payments to suppliers, which automatically leads to an increase in receivables.

The inconsistency of the regulatory framework, institutional and institutionary inconsistencies, in particular, the lack of proper scientific substantiation and planning of defense expenditures also leads to a decrease in the effectiveness of financial regulation of the defense industry. The situation is exacerbated by the fact that the formation of the defense budget is largely non-transparent. Adequate systematic, effective control over the spending of defense budget funds has not been established.

Today, based on the experience of approaches to defense planning in NATO member countries, the main target function is not the number of troops or units of military equipment, but the factor of the military structure's ability to perform certain actions. And financial regulation in the troop support system should be aimed at building the ability of the Armed Forces to respond to challenges and threats which are detected by intelligence.

Therefore, based on the experience of other countries, the task is to formalize this objective function in the form of the so-called "Standard catalog of capabilities of typical military structures" [14].

According to this approach, seven main categories are outlined for the Armed Forces. Two of them are: "deployment and mobility" and "logistics" [14]. Much work has been done in this direction by the MDU, in particular, a codification system in line with NATO standards has been introduced; a system of military logistics management has been formed, the structural subdivisions of which are gaining practical experience in organizing the supply of military units, including that in the condition of conducting combat operations.

The reform of military logistics is carried out in such a way that it is capable of organizing the proper accumulation, safe storage and formation of a system of efficient supply of troops.

This requires effective funding for military logistics and proper integration with NATO's logistics structures. This goal is formalized as a strategic goal №4 of the State Program for the Development of the Armed Forces of Ukraine "Creation of a unified logistics system and improvement of the medical support system of the Armed Forces in accordance with NATO standards" [19]. It is directly related to the strategic goal №2 "Improvement of the defense planning system, introduction of transparent and effective resource management in the Ministry of Defence of Ukraine and the Armed Forces of Ukraine using modern Euro-Atlantic approaches" [14, 33-36].

Table 4. Financing of the unified logistics system and improvement of the medical support system of the Armed Forces in accordance with NATO standards.

\begin{tabular}{|l|c|c|c|c|c|}
\hline \multicolumn{2}{|c|}{ The amount of funding } & \multicolumn{4}{c|}{ Years } \\
\cline { 3 - 6 } & $\mathbf{2 0 1 7}$ & $\mathbf{2 0 1 8}$ & $\mathbf{2 0 1 9}$ & $\mathbf{2 0 2 0}$ \\
\hline $\begin{array}{l}\text { Total under the state program, } \\
\text { UAH million }\end{array}$ & 100939.38 & 7173.21 & 22211.95 & 33402.10 & 38152.12 \\
\hline $\begin{array}{l}\text { For the strategic goal №4 of the } \\
\text { State Program, UAH mln }\end{array}$ & 1796.06 & 2899.22 & 9379.27 & 9284.77 & 10232.8 \\
\hline Share of the total amount, \% & 31.5 & 40.42 & 42.23 & 27.79 & 26.82 \\
\hline
\end{tabular}


The analysis of the dynamics of the implementation of the planned funding of military logistics and work to establish proper integration with NATO logistics structures is given in Table 4 [14]. According to the data presented in Table 4, it is possible to indicate the presence of two opposite trends in the financial regulation of military logistics in the military support system. First, the analysis of the dynamics of funding of the strategic goal №4 of the State Program for the period 2017-2020 indicates an increase in funding in absolute amount by more than 3.5 times. Secondly, there is a reduction of the share of the total amount for the implementation of this paragraph of the State Program by more than 1.5 times [14, 37-40].

The reduction of the share of the total amount indicates a certain decrease in the attention of the MDU leadership to the importance of military logistics reform and a decrease in opportunities for potential growth of the efficiency of military logistics reform in the near future.

The creation of an effective system of military logistics is also due to the ability to use modern information systems, support and decision-making systems. These systems, as the experience of the recent military conflict in Nagorno-Karabakh has shown, must be based on reliable and efficient mathematical models. As military actions are often characterized by the sudden cutting of supply options through certain, previously defined routes, which is associated with the actions of the enemy (increasing risk $\varepsilon$ ), we have developed a mathematical model of supply with the choice of alternative routes. The proposed technique is one example of the use of genetic algorithms.

To do this, we model the logistics supply system of military units with a pseudocanonical oriented graph (hereinafter, digraph). Weak section of the supply route is the capacity of the corresponding digraph arc which is under threat. This, in the definitions of graph theory, is the weight of the arc $\delta(x) \geq 0$, where $x$ is the number of cargo in kind that will pass per time unit through each arc of the digraph. Provided there is no loss of cargo for the whole digraph as a model of the logistics system of supply of military units the following equation is correct:

$$
\sum_{i}^{n} \delta_{i}^{\text {enter }}(x)=\sum_{j}^{m} \delta_{j}^{\text {entrance }}(x)
$$

where $n$ is the number of points of departure of goods, $m$ is the number of points of receipt of goods, $i, j$ are indices of output / input arcs of the digraph, which leave / enter / nodes - points of departure / receipt of goods.

Each of the arcs, according to the degree of risk of transportation has a so-called capacity $x \leq x^{\max }$, where $x^{\max }$ is the maximum number of cargo in kind that will pass per time unit by the corresponding arc of the digraph.

That is, the weight of the arc of the digraph becomes a function of time and a function of risk:

$$
\{\delta(x)=\varphi(\tau) \delta(x)=f(\varepsilon)
$$

The weight of the transportation route is equal to the sum of the weight of all arcs that are parts of the mentioned route. Since, during military actions, it is important not only to deliver a certain cargo to a certain military unit, but also at a certain time, we impose restrictions $\tau \leq \tau^{\max }$.

Then the problem under certain conditions and constraints can be solved by the algorithm of the standard problem of graph theory - the problem of flow control.

The developed mathematical model can be used in any system of support and decisionmaking of military logistics as a separate additional module. 


\section{Conclusions}

The current problems of financial regulation of the defense industry and the provision of troops are the result of improper prioritization of strengthening the state's defense capabilities for the period 1991-2013. The study found that for the period up to 2014, the share of expenditures on the development of armaments, military equipment and military logistics was less than a quarter of the minimum threshold limit value and, even under this condition, cash expenditures for these purposes were much lower than planned.

The rate of operational capability of the latest and modernized equipment for the Armed Forces is insufficient for the timely replacement of old and damaged machinery and equipment. The permanent lack of the necessary amounts of financial resources for these purposes increases the degree of threats and necessitates the formation of an effective system of management of available financial and material resources.

The problem of forming a gap between the amounts planned in the state budget and cash expenditures lies mostly in the uneven quarterly allocation of money by the Ministry of Finance. The allocation of budget amounts occurs mainly in the last quarter of the financial year, which significantly reduces their effective use, forcing the advance payment to suppliers, which, in turn, leads to an increase in receivables of the Ministry of Defence of Ukraine. The inconsistency of the regulatory framework, institutional and institutionary inconsistencies, in particular, the lack of proper scientific substantiation of planned expenditures also leads to a decrease in the effectiveness of financial regulation of the defense industry. For the most part, the formation of the armed forces budget is nontransparent, and proper systematic, effective control over the expenditure of the defense budget has not been established.

The mechanism of planning the defense needs of the budget process, their financing, effective management of financial, production and material resources is extremely imperfect and needs to be reformed. The military logistics system needs to be reformed. The task of adequate financial support for the formation of a highly efficient centralized logistics service with modern information tools and decision support system is quite urgent.

\section{References}

1. Korotkyi, V. (2020). 1100 Russian tanks and 330 warplanes along the border with Ukraine. Ukrinform. https://www.ukrinform.ua/rubric-world/3055672-1100rosijskihtankiv-i-330-bojovih-litakiv-uzdovz-kordonu-z-ukrainou.html

2. Connable, B., Doll, A., Demus, A., Massicot, D., Reach, C., Atler, A., Mackenzie, W., Povlock, M., \& Skrabala, L. (2020). Russia's Limit of Advance. Analysis of Russian Ground Force Deployment Capabilities and Limitations. RAND Corporation. https://www.rand.org/pubs/research reports/RR2563.html

3. Sahaniuk, F., \& Nalivaiko, A. (2019). Going is near determination of strategic aims of development of troops (forces) for forming of the Strategic defensive bulletin of Ukraine. Collection of scientific works of the Center for Military Strategic Studies, 3(67), 6-8. https://doi.org/10.33099/2304-2745/2019-3-67/6-8

4. National Security and Defense Council of Ukraine. (2017). About the State program of development of the Armed Forces of Ukraine for the period till 2020, Decision on December 29, 2016. Document n0017525-16. https://zakon.rada.gov.ua/laws/show/n0017525-16\#Text

5. Latysheva, O., Rovenska, V., Smyrnova, I., Nitsenko, V., Balezentis, T., \& Streimikiene, D. (2020). Management of the sustainable development of machinebuilding enterprises: a sustainable development space approach. Journal of Enterprise Information Management, 34(1), 328-342. https://doi.org/10.1108/JEIM-12-2019-0419 
6. Arsawan, I.W.E., Koval, V., Rajiani, I., Rustiarini, N.W., Supartha, W.G. \& Suryantini, N.P.S. (2020). Leveraging knowledge sharing and innovation culture into SMEs sustainable competitive advantage. International Journal of Productivity and Performance Management (in press). https://doi.org/10.1108/IJPPM-04-2020-0192

7. Kalinichenko, A., \& Havrysh, V. (2019). Feasibility study of biogas project development: technology maturity, feedstock, and utilization pathway. Archives of Environmental Protection, 45(1), 68-83. http://dx.doi.org/10.24425/aep.2019.126423

8. Behma, V.M., Shemaiev, V.M., \& Tolok, P.O. (2017). Reforming and development of defense enterprises in the context of the economic potential of Ukraine. Black sea economic studies, 23, 32-36.

9. Chepkov, I.B., Zubariev, V.V., \& Sverhunov, O.O. (2018). System approach to evaluation military-technical aspects of ensuring the state of military security in conditions new global political and resource changes. Weapons and military equipment, 2, 3-7. https://doi.org/10.34169/2414-0651.2018.2(18).3-7

10. Tymoshenko, R.I., \& Lobko, M.M. (2018). Problems concerning improvement of planning of defence of Ukraine. Science and defense, 1, 11-17.

11. Danyliuk, V., Riepina, I., Shafalyuk, O., Kovylina, M., \& Nitsenko, V. (2020). Functional and investment strategies of technical development of enterprises. Naukovyi Visnyk Natsionalnoho Hirnychoho Universytetu, 3, 115-121.

12. Calcara, A. (2018). Cooperation and conflict in the European defence-industrial field: the role of relative gains. Defence Studies, 18(3),1-24.

13. European Defence Agency. Data Analysis. https://eda.europa.eu/publications-anddata/defence-data

14. Ministry of Defense of Ukraine. (2020). Execution of the state budget by the Ministry of Defense of Ukraine. https://www.mil.gov.ua/diyalnist/byudzhet-ta-vikonannyaczilovix-program/vikonannya-ministerstvom-oboroni-ukraini-derzhavnogo-byudzhetu/

15. Ukrainian Military Pages. (2020). How many and what weapons will the Ministry of Defense buy in 2020. https://www.ukrmilitary.com/2020/05/zakupivli-mou.html

16. Pauk, O., \& Sokol, D. (2020). Advantages of the Marine-Based LV Zenit Project. Advanced Space Law, 6, 83-86. https://doi.org/10.29202/asl/6/10

17. Halunko, V., Buhlak, Y., \& Pauk, O. (2020). International Legal Regulation of the Missile Technology Control Regime in the Aspect of Private Space Company Activities. Advanced Space Law, 5, 34-47. https://doi.org/10.29202/as1/2020/5/4

18. Pavlovs'kij, I.V., Chepkov, I.B., Zubariev, V.V., Smirnov, V.O., \& Sverhunov, O.O. (2017). Military-technical policy of Ukraine: problems of formation and realization in conditions of crisis phenomena and resource constraints. Weapons and military equipment, 3(15), 3-7. https://doi.org/10.34169/2414-0651.2017.3(15).3-7

19. Gochua, A., \& Zedelashvili, T. (2020). Cyber Threats and Asymmetric Military challenges In the Context of Nuclear Security: Ukrainian and International Cases Analysis. Ukrainian Policymaker, 7, 20-27. https://doi.org/10.29202/up/7/3

20. Andriushchenko, K., Tepliuk, M., Boniar, S., Ushenko, N., \& Liezina, A. (2019). Influence of cost drivers on value-oriented management of investment activity of companies. Investment Management and Financial Innovations, 9(1), 353-364. http://doi.org/10.21511/imfi.16(3).2019.31

21. Avanesova, N.E. (2017). The system approach to formation of strategy of economic security of the defense industry of Ukraine in conditions of European integration. The bulletin of transport and industry economics, 57, 20-27.

22. Lapytskyi, S.V., Zubariev, O.V., \& Sverhunov, O.O. (2020). Systematic analysis and evaluation of the eff activeness of science and technology development systems in the implementation of the scientific and technical component of the military and technical 
policy of the states. Weapons and military equipment, 1(25), 3-11. https://doi.org/10.34169/2414-0651.2020.1(25).3-11

23. Olejarz, T., Nitsenko, V., Chukurna, O., \& Mykhailova, M. (2018). Evaluation of factors influencing labour performance of machine-building enterprises in mining industry. Naukovyi Visnyk Natsionalnoho Hirnychoho Universytetu, 1, 154-162. https://doi.org/10.29202/nvngu/2018-1/2

24. Hutsaliuk, O., Koval, V., Tsimoshynska, O., Koval, M., \& Skyba, H. (2020). Risk Management of Forming Enterprises Integration Corporate Strategy. TEM Journal, 9(4), 1514-1523. https://doi.org/10.18421/TEM94-26

25. Tolok, P. (2019). Interaction of Ukraine's defense industry companies with subsidiaries of the external environment: context of financial security. Market infrastructure, 30, 235-240.

26. Petrenko, I., \& Filipchuk, V. (2020). Approaches to the Differentiation of Political and Public Decisions. Future Human Image, 14, 56-63. https://doi.org/10.29202/fhi/14/7

27. Shmygol, N., Schiavone, F., Trokhymets, O., Pawliszczy, D., Koval, V., Zavgorodniy, R., \& Vorfolomeiev A. (2020). Model for assessing and implementing resourceefficient strategy of industry. CEUR Workshop Proceedings, 2713, 277-294.

28. Andriushchenko, K., Rudyk, V., Riabchenko, O., Kachynska, M., Marynenko, N.... \& Kuchai, O. (2019). Processes of managing information infrastructure of a digital enterprise in the framework of the «Industry 4.0» concept. Eastern-European Journal of Enterprise Technologies, 1/3(97), 60-72. http://doi.org/10.15587/1729$\underline{4061.2019 .157765}$

29. Soroka, L. (2021). Space Doctrine and the Future of the Space Industry. Philosophy and Cosmology, 26, 25-34. https://doi.org/10.29202/phil-cosm/26/2

30. UkrOboronProm. (2020). Official site. https://ukroboronprom.com.ua/uk/

31. League of Defense Companies of Ukraine. (2020). Official site. http://ldc.org.ua/

32. Ukrspecexport. (2020). Official site. http://www.ukrspecexport.com/

33. Bondarenko, O.H. (2018). Essence of logistic support management of security and defense sector formation joint actions during crises situations which are threatening of to the State Securiry of Ukraine. Scientific notes of Tavriya National University. Public $\begin{array}{llll}\text { Administration } & \text { Series, } & 29(68), & 1,\end{array}$ http://nbuv.gov.ua/UJRN/sntvupa 2018 $29 \quad 1 \quad 40$

34. Havrysh, V.I., \& Nitsenko, V.S. (2016). Current state of world alternative motor fuels market. Actual problems of economics, 7(181), 41-52.

35. Yankovyi, O., Goncharov, Y., Koval, V., \& Lositska, T. (2019). Optimization of the capital-labor ratio on the basis of production functions in the economic model of production. Naukovyi Visnyk Natsionalnoho Hirnychoho Universytetu, 4, 134-140.

36. Kalinichenko, A., Havrysh, V., \& Nitsenko, V. (2019). Alternative Vehicle Fuel Management: Impact on Energy Security Indicators. In: Krakowiak-Bal A., Vaverkova M. (eds) Infrastructure and Environment. Springer, Cham, 367-374.

37. Pylypenko, H., Lytvynenko, N., \& Barna, T. (2019). Socio-Cultural Context of Innovative Development. Philosophy and Cosmology, 23, 98-111. https://doi.org/10.29202/phil-cosm/23/9

38. Reva, N. (2018). Logic, Reasoning, Decision-Making. Future Human Image, 10, 76-84. https://doi.org/10.29202/fhi/10/8

39. Kalinichenko, A., Havrysh, V., \& Perebyynis, V. (2017). Sensitivity analysis in investment project of biogas plant. Applied ecology and environmental research, 15(4), 969-985. http://dx.doi.org/10.15666/aeer/1504_969985

40. Orzechowski, M. (2019). Conflict in Donbass as a Case Study of the Deconstruction of Ukraine's Statehood. Present State and Prospects for Regulating It. Ukrainian Policymaker, 5, 53-60. https://doi.org/10.29202/up/5/6 